ROZ D Z I A E 10 .

\title{
ZNACZENIE DZIERŻAWY W ZAGOSPODAROWANIU GRUNTÓW ROLNYCH SKARBU PAŃSTWA
}

\author{
Jarosław Mioduszewski ${ }^{1}$
}

\section{Wstęp}

Wykorzystanie instytucji dzierżawy w rolnictwie polskim miało niewielkie znaczenie przed uruchomieniem procesu przekształceń własnościowych w państwowym sektorze rolnictwa ${ }^{2}$. Do 1990 roku dzierżawa, jak wskazuje Wojciech Ziętara ${ }^{3}$, była zjawiskiem marginalnym i dotyczyła niespełna 4\% gruntów rolnych (około 761 tys. ha) dzierżawionych przez rolników z Państwowego Funduszu Ziemi oraz w ramach dzierżaw międzysąsiedzkich. Natomiast w krajach Unii Europejskiej, dzierżawa jest głównym narzędziem stymulującym przemiany w strukturze obszarowej rolnictwa, a także służącym poprawie jego efektywności. Wysoki i jednocześnie systematycznie wzrastający udział dzierżawy gruntów rolnych notowany był w kilku krajach Unii Europejskiej. Największy udział gruntów dzierżawionych w ogóle użytkowanych gruntach rolnych w latach 90.

\footnotetext{
${ }^{1}$ Dr Jarosław Mioduszewski, Uniwersytet Warmińsko-Mazurski.

2 W.Ziętara, Dzierżawa ziemi i jej rola $w$ krajach Unii Europejskiej $i$ w Polsce, [w:] Dzierżawa ziemi jako czynnik przemian struktury agrarnej w Polsce, W. Ziętara (red.), SGGW, Warszawa 1999, s. 8-10.

3 Tenże, Dzierżawa nieruchomości rolnych z Zasobu Własności Rolnej Skarbu Państwa, [w:] tamże, s. 78.
} 
XX stulecia odnotowano we Francji, Belgii i Niemczech. Kształtował się on na poziomie ponad $60 \%$. W tych krajach dzierżawa gruntów rolnych stała się podstawowym czynnikiem kształtującym strukturę obszarową prowadzącą jednocześnie do zmniejszania się liczby gospodarstw, przy wzroście ich przeciętnej powierzchni. Można przyjąć, że w państwach UE zmiany w powierzchni gospodarstw warunkowała instytucja dzierżawy gruntów. System dzierżaw w Polsce nie był rozwinięty w tak dużym stopniu, jak w krajach UE, jednak jak zakładano mógł on przyczynić się do przemian struktury obszarowej w związku z wprowadzonymi przekształceniami własnościowymi w państwowym sektorze rolnictwa.

Zmiany ustrojowe zachodzące w Polsce po 1989 roku w istotny sposób zmieniły sytuację społeczno-gospodarczą, w tym również podejście do własności prywatnej i formalnoprawnych rozwiązań umożliwiających rozwój dzierżawy gruntów rolnych. W Polsce dzierżawę traktowano jako tymczasową formę użytkowania nieruchomości rolnych, czemu nie sprzyjały również rozwiązania opublikowane w kodeksie cywilnym, które zawierały różnego rodzaju ograniczenia obrotu własnościowego ${ }^{4}$. Według Adama Sadowskiego ${ }^{5}$ zasadniczy wpływ na odtwarzanie praw własności nieruchomości rolnych wywarły zmiany wprowadzone w ustawie z dnia 29 grudnia 1989 r. o zmianie Konstytucji Polskiej Rzeczypospolitej Ludowej $^{6}$, które zgodnie z zapisami art. 7 zagwarantowały ochronę własności, prawa dziedziczenia oraz poręczyły ochronę własności osobistej. Ponadto gwarantowały odejście od wcześniejszego podziału na własność państwową i indywidualną oraz skłaniały się ku klasycznemu modelowi praw własności. Kolejna regulacja prawna, z 29 września 1990 roku, dotyczyła zmian ustawy o gospodarce gruntami i wywłaszczeniu nieruchomości ${ }^{7}$. Zgodnie z zapisami art. 2 ust. 1 wyłączono z niej grunty będące

${ }^{4}$ R. Marks-Bielska, Rynek ziemi rolniczej $w$ Polsce - uwarunkowania i tendencje rozwoju, Wydawnictwo UWM, Olsztyn 2010, s. 287.

${ }^{5}$ A. Sadowski, Własność a użytkowanie gruntów rolnych. Zarys tendencji rozwojowych, Wydawnictwo Uniwersytetu w Białymstoku, Białystok 2009, s. 301.

${ }^{6}$ Dz.U. 1989 r. nr 75, poz. 444.

${ }^{7}$ Dz.U. 1990 r. nr 79, poz. 464. 
w zarządzie państwowych gospodarstw rolnych, a uprawnienia odnośnie do gruntów stanowiących własność Skarbu Państwa będących w ich zarządzie uregulowano w odrębnej ustawie, tj. ustawie z 19 października 1991 r. o gospodarowaniu nieruchomościami rolnymi Skarbu Państwa. Jak wskazuje Konrad Marciniuk ${ }^{8}$, nowelizacja Kodeksu cywilnego dokonana w 1990 roku, na podstawie której sformułowano pojęcie „nieruchomość rolna”, była związana z liberalizacją obrotu nieruchomościami rolnymi. Uchylono wówczas obowiązujące wcześniej konstrukcje normatywne określające podmiotowe, jak i przedmiotowe przesłanki obrotu nieruchomościami rolnymi (art. 160, 161, 163 k.c. ${ }^{9}$ ), znosząc ograniczenia dotyczące nabywania nieruchomości rolnych w drodze umów.

Realizowany od 1992 roku proces przekształceń własnościowych w państwowym sektorze rolnictwa ukierunkowany został na ograniczanie własności państwowej na rzecz poszerzenia i umacniania własności prywatnej. Utworzonej Agencji Własności Rolnej Skarbu Państwa powierzono wykonywanie praw własności i innych praw rzeczowych w stosunku do mienia z likwidowanych państwowych przedsiębiorstw gospodarki rolnej oraz z innych tytułów ${ }^{10}$. Proces obejmował trzy zasadnicze etapy, tj. przyjęcie nieruchomości rolnych, przygotowanie, a następnie zagospodarowanie. Początkowo proces ten realizowano głównie przez prywatyzację zarządzania, czyli administrowanie i dzierżawę nieruchomości rolnych, a następnie prywatyzację własności (sprzedaż oraz w mniejszym stopniu - nieodpłatne przekazanie dla różnych instytucji i organizacji). Podejmowane działania wskazują, że państwo zmierzało do możliwie jak najszybszego trwałego zagospodarowania (sprzedaży) gruntów pozostających w Zasobie Własności Rolnej, również i tych dotychczas dzierżawionych ${ }^{11}$. Dzierżawa jako

${ }^{8}$ K. Marciniuk, Pojęcie nieruchomości rolnej jako przedmiotu reglamentacji obrotu własnościowego, „Studia Iuridica Lublinensia” 2017, t. XXVI, nr 1, s. 93-114

${ }^{9}$ Dz.U. z 1990 r. nr 55, poz. 321

${ }^{10}$ Rynek ziemi rolniczej stan i perspektywy, „Analizy Rynkowe” 2013, nr 16, s. 26.

11 J. Mioduszewski, Sposoby zagospodarowania nieruchomości rolnych Skarbu Państwa na przykładzie regionu warmińsko-mazurskiego, [w:] Przekształcenia własnościowe $w$ rolnictwie - 25 lat historii i doświadczeń, E. Niedzielski, R. Kisiel 
forma gospodarowania mieniem w swej istocie oddziela prawo własności od prawa użytkowania. Instytucja dzierżawy daje uprawnienia do czerpania pożytków z jej użytkowania bez konieczności zakupu, umożliwiając wzrost skali produkcji oraz poprawy efektywności wykorzystania pozostałych czynników produkcji w rolnictwie ${ }^{12}$.

Celem rozdziału jest wskazanie znaczenia dzierżawy w zagospodarowaniu gruntów rolnych Skarbu Państwa.

\subsection{Mechanizm i zasady gospodarowania Zasobem Własności Rolnej Skarbu Państwa}

Skarb Państwa na mocy ustawy z dnia 19 października 1991 r. o gospodarowaniu nieruchomościami rolnymi Skarbu Państwa, zgodnie z art. 5, powierzył wykonywanie prawa własności i innych praw rzeczowych w odniesieniu do nieruchomości rolnych określonych w art. 1 i art. 2 przekazanych do Zasobu Własności Rolnej Skarbu Państwa ${ }^{13}$, Krajowemu Ośrodkowi Wsparcia Rolnictwa (KOWR) ${ }^{14}$. Jest on kontynuatorem działalności prowadzonej przez Agencję Nieruchomości Rolnych - następcę prawnego Agencji Własności Rolnej Skarbu Państwa, w zakresie gospodarowania Zasobem Własności Rolnej Skarbu Państwa, którą powołano w październiku 1991 roku mocą ustawy o gospodarowaniu nieruchomościami rolnymi Skarbu Państwa. Zadaniem Agencji było przejęcie, a następnie

(red.), Towarzystwo Naukowe Współczesnego Zarządzania w Krakowie, Kraków 2017, s. 19.

${ }^{12}$ B. Tańska-Hus, Dzierżawa jako instrument mobilności ziemi w Polsce i UE, „Zagadnienia Ekonomiki Rolnej” 2010, t. 1, nr 322, s. 25-26.

${ }^{13}$ Ustawa z dnia 19 października 1991 r. o gospodarowaniu nieruchomościami rolnymi Skarbu Państwa, Dz.U. z 1991 r. nr 107, poz. 464.

${ }^{14}$ Krajowy Ośrodek Wsparcia Rolnictwa powstał 1 września 2017 roku na mocy ustawy z dnia 10 lutego 2017 r. o Krajowym Ośrodku Wsparcia Rolnictwa (Dz.U. z 2017 r., poz. 623) i który przejął zadania dotychczasowej Agencji Rynku Rolnego oraz Agencji Nieruchomości Rolnych. 
restrukturyzacja i prywatyzacja mienia byłych Państwowych Gospodarstwach Rolnych oraz nieruchomości rolnych przejętych z Państwowego Funduszu Ziemi i innych tytułów.

Rysunek 10.1. Powierzchnia gruntów przejętych do Zasobu WRSP i pozostająca do rozdysponowania w podziale na województwa według stanu na 31 grudnia 2018 roku

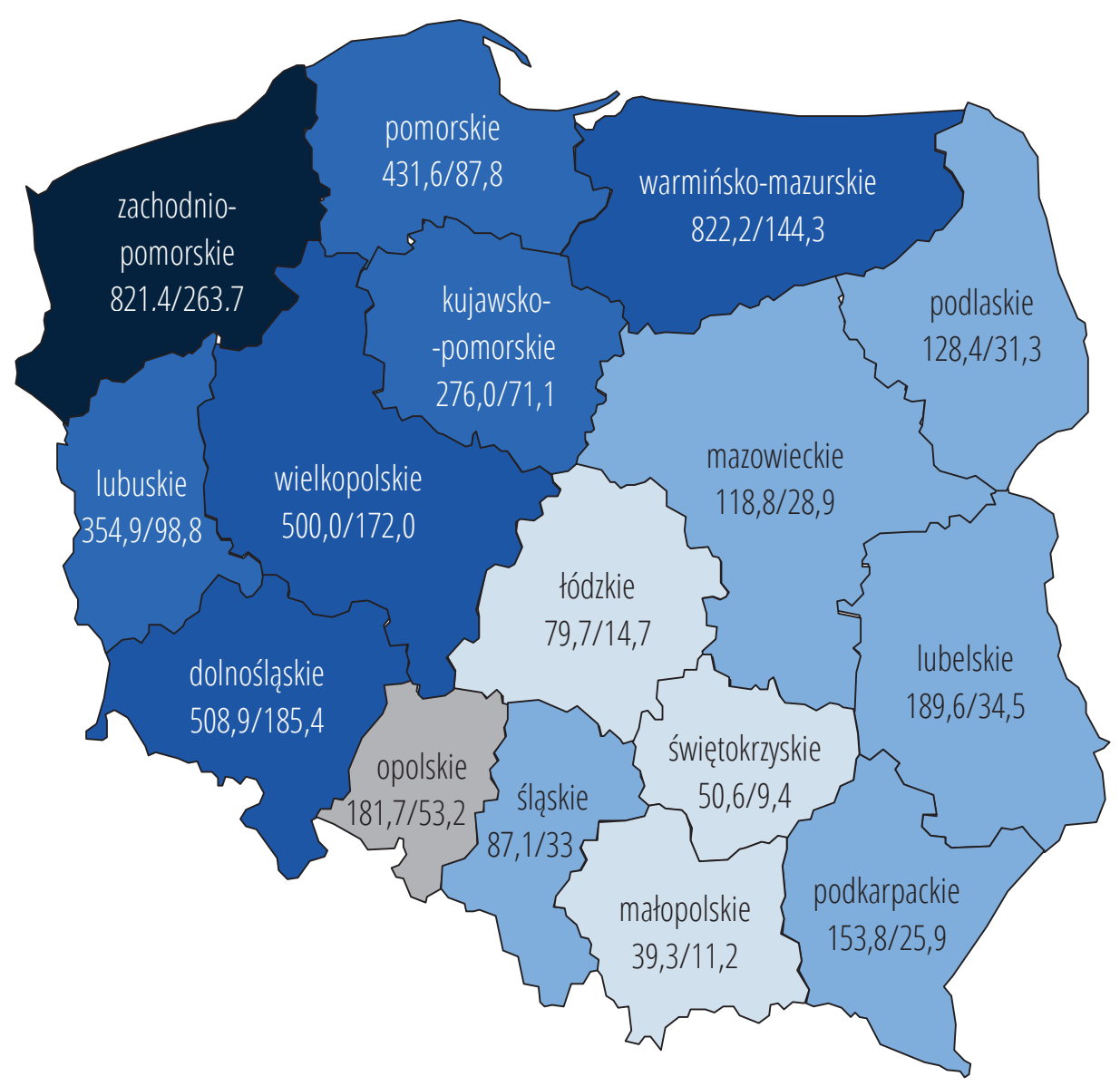

Polska:

4744,03 tys. ha - grunty przejęte do Zasobu WRSP

1368,9 tys. ha $(28,9 \%)$ - grunty do rozdysponowania z Zasobu WRSP

Źródło: opracowanie własne na podstawie danych ze Sprawozdania z działalności Krajowego Ośrodka Wsparcia Rolnictwa w 2018 roku, KOWR, Warszawa 2019, s. 217. 
Agencja przejęła do Zasobu Własności Rolnej Skarbu Państwa od początku prowadzonej działalności do końca 2018 roku ogółem ponad 4744,0 tys. ha, z czego 3762,1 tys. ha (79\%) pochodziło z 1666 zlikwidowanych Państwowych Przedsiębiorstw Gospodarki Rolnej (PPGR), a ponad 608 tys. ha $(12,8 \%)$ z Państwowego Funduszu Ziemi (PFZ). Państwowe Gospodarstwa Rolne (PGR) położone były głównie w rejonach północnej i zachodniej Polski, z kolei grunty PFZ przede wszystkim w rejonie Polski północno-zachodniej i północno-wschodniej. Takie przestrzenne rozmieszczenie gruntów znalazło odzwierciedlenie w działaniach związanych z przejmowaniem, jak i zagospodarowaniem nieruchomości rolnych Skarbu Państwa ${ }^{15}$. Ma to swoje konsekwencje także w obecnej lokalizacji, gdzie 1368,9 tys. ha $(28,9 \%)$ pozostaje w zasobie WRSP, a z tego 74,7\% (1,02 mln ha) znajduje się na obszarze 7 województw: warmińsko-mazurskiego, pomorskiego, zachodniopomorskiego, kujawsko-pomorskiego, lubuskiego, wielkopolskiego i dolnośląskiego (rysunek 10.1.).

Ponadto do Zasobu WRSP, oprócz gruntów, przejęto majątek trwały pochodzący z byłych PGR-ów i innych podmiotów, o wartości netto ponad 7,3 mld zł, majątek obrotowy o wartości około 1,3 mld zł, który wystarczyłby na pokrycie 64,9\% zobowiązań byłych PGR-ów. Wymóg samofinansowania prowadzonej działalności przez Agencję spowodował, że do Zasobu WRSP w pierwszej kolejności przejmowano Państwowe Gospodarstwa Rolne lepiej wyposażone w majątek trwały i ruchomy oraz posiadające wyższy wskaźnik pokrycia zadłużenia majątkiem obrotowym, co zapewniało stabilność sytuacji ekonomiczno-finansowej Agencji oraz umożliwiało przygotowanie dalszych działań związanych z ich zagospodarowaniem. Kolejnym kryterium przy przejmowaniu przedsiębiorstw było posiadanie uregulowanego stanu prawnogeodezyjnego gruntów, które można było szybko zagospodarować ze względu na złożone do Agencji wiarygodne

${ }^{15}$ R. Przygodzka, J, Mioduszewski, The agricultural land market in Poland and its characteristics, [w:] Challenges and Prospects for Innovation between 2014-2020. Papers of scientific days, Karoly Robert College, K. Takács György (red.), Gyöngyös 2016, s. 1315-1323. 
oferty zakupu lub dzierżawy ${ }^{16}$. Bardziej skomplikowanym etapem procesu przekształceń własnościowych gospodarstw państwowych było przysposobienie mienia do zagospodarowania, obejmujące: przygotowanie programu restrukturyzacji, uporządkowanie stanu geodezyjnoprawnego, ogłoszenie i przeprowadzenie przetargu na składniki mienia restrukturyzowanych gospodarstw, wycena i wydanie mienia. Państwowe Gospodarstwa Rolne w momencie ich przejęcia do Zasobu WRSP traciły osobowość prawną i od tego momentu funkcjonowały jako gospodarstwa rolne Skarbu Państwa w tymczasowym zarządzie. W okresie tymczasowego zarządu Agencja sprawowała uprawnienia właścicielskie, a w jej imieniu zarządzał nim oraz przygotowywał program restrukturyzacji tymczasowy zarządca. Program ten miał określić najlepszy sposób zagospodarowania majątku, z uwzględnieniem aspektu ekonomicznego, prawnego, społecznego oraz politycznego, który w swej istocie wskazywał, że „dominującą formą organizacji rolniczej przestrzeni produkcyjnej jest i będzie gospodarstwo rodzinne”. Strategia prowadzenia działalności została zapisana w dokumencie „Kierunki działania Agencji Własności Rolnej Skarbu Państwa"17, w którym zawarto główne założenia dotyczące sposobu przejmowania, restrukturyzacji i rozdysponowania nieruchomości rolnych Skarbu Państwa. Odzwierciedleniem tych założeń stały się zapisy zawarte w Konstytucji Rzeczypospolitej Polskiej z dnia 2 kwietnia 1997 r. ${ }^{18}$, gdzie w art. 23 wskazano, że „Podstawą ustroju rolnego państwa jest gospodarstwo rodzinne”. W założeniach procesu przekształceń własnościowych wskazywano, że rozwój rolnictwa miał polegać na stopniowej koncentracji ziemi i produkcji, a więc zmniejszeniu liczby gospodarstw w regionach o dużym ich rozdrobnieniu, a w rejonach o dużej koncentracji ziemi państwowej - powiększeniu obszaru oraz tworzeniu

16 J. Rzeszutek, Zagospodarowanie nieruchomości rolnych przejętych do Zasobu Własności Rolnej Skarbu Państwa w Makroregionie Pótnocno-Wschodnim, [w:] Perspektywy rozwojowe gospodarstw rolnych pótnocno-wschodniej Polski, Wydawnictwo ART, Olsztyn 1998, s. 58.

${ }^{17}$ Kierunki działania Agencji Własności Rolnej Skarbu Państwa, załącznik nr 1 do Raportu z działalności AWSP za 1992 rok, Warszawa 1993.

18 Dz.U. z 1997 r. nr 78, poz. 483. 
nowych gospodarstw rolniczych ${ }^{19}$. W każdym z opracowanych programów restrukturyzacyjnych wskazano możliwie dużą liczbę nieruchomości do odrębnego zagospodarowania. W regionach o dużym udziale gruntów PGR, zakres i kierunek procesów restrukturyzacyjnych determinowała dotychczasowa organizacja rolniczej przestrzeni produkcyjnej. Ograniczało to możliwość podziału PGR na mniejsze jednostki, a restrukturyzacja polegała na wyłączeniu do odrębnego zagospodarowania jedynie peryferyjnych gruntów - często pojedynczych działek, dla rolników zamierzających powiększyć własne gospodarstwa. Restrukturyzacja prowadziła również do wydzielenia gruntów na inne cele, np. gruntów niezbędnych gminom na realizację zadań własnych, czy też gruntów nierolnych.

W całym 27-letnim okresie realizacji zadań wynikających z polityki państwa przez KOWR (wcześniej ANR/AWRSP) można wyróżnić pięć charakterystycznych okresów w gospodarowaniu nieruchomościami rolnymi Skarbu Państwa. W pierwszym okresie (lata 1992-1995) działania skupione były na przejęciu nieruchomości rolnych do Zasobu WRSP. W tym okresie przejęto ponad 4,4 mln ha, a grunty te w głównej mierze pochodziły z 1666 przejętych Państwowych Gospodarstw Rolnych. Na podstawie opracowanych planów restrukturyzacji dokonywano wyboru formy zagospodarowania. Procesowi zagospodarowania towarzyszył niewielki popyt na ziemię, głównie z powodu z niskiej opłacalności produkcji rolniczej, a także z faktu, że niedobór ziemi występował w rejonach o niewielkim udziale gospodarstw państwowych w strukturze użytkowania gruntami rolnymi. Niskie efekty przyniosła akcja osadnictwa oraz inne formy zachęty przemieszczania się rolników z terenów o rozdrobnionej strukturze agrarnej na tereny o dużym udziale gruntów popegeerowskich. W efekcie, większość gruntów przejęta do zasobu WRSP (ponad 2,7 mln ha - 62\%) została zagospodarowana głównie w formie dzierżawy, a niewielką część

${ }^{19}$ J. Mioduszewski, Podaż ziemi z gospodarstw państwowych do zagospodarowania przez rolników indywidualnych, [w:] Udział rolników indywidualnych $w$ przeksztatceniach gospodarstw państwowych, E. Niedzielski, J. Cichoń (red.), Wydawnictwo Akademii Rolniczo-Technicznej, Olsztyn 1995, s. 46-48. 
gruntów (332 tys. ha - 7,5\%) przekazano w administrowanie gospodarstwom rolnym Skarbu Państwa zdolnym efektywnie prowadzić działalność.

W latach 1996-2003 (drugi okres) w dalszym ciągu realizowano proces zagospodarowywania przejętych gruntów, głównie poprzez dzierżawę i sprzedaż gruntów, tj. średnio około 150 tys. ha w skali roku. W tym okresie zanotowano wzrost popytu na grunty na tych obszarach, gdzie wcześniej występował w ograniczonym zakresie. Wzrost ten wynikał w głównej mierze ze zmian sytuacji społeczno-gospodarczej i uwarunkowań rynkowych. W zagospodarowaniu nieruchomości rolnych w tym okresie, Agencja miała swobodę w realizacji powierzonych jej zadań, ze względu na uregulowanie przejętego zadłużenia po byłych Państwowych Gospodarstwach Rolnych, tj. zobowiązań wobec instytucji i kontrahentów do końca 2000 roku na mocy podpisanych stosownych porozumień i ugód ${ }^{20}$. Okres ten charakteryzował się także relatywnie dużą zmiennością w podejściu do gospodarowania Zasobem. Mimo że większość przejętych gruntów była zagospodarowana, to w 1997 roku można było zaobserwować niekorzystną, nasilająca się w następnych latach, tendencję do rezygnacji z umów przez dotychczasowych dzierżawców. Wpłynęło to na zwiększenie znaczenia innych form zagospodarowania nieruchomości rolnych Skarbu Państwa, w tym administrowania. Administrowanie jako forma zagospodarowania przewidziana była głównie dla tych gospodarstw rolnych Skarbu Państwa, których nie można było szybko wydzierżawić lub sprzedać, a jednocześnie były one w stanie prowadzić działalność bez konieczności zewnętrznego ich zasilania. Ponadto ze względu na krótką perspektywę wejścia Polski do Unii Europejskiej w 2003 roku wprowadzono na mocy ustawy o kształtowaniu ustroju rolnego ${ }^{21}$ zapisy do ustawy z dnia 19 października 1991 r. o gospodarowaniu nieruchomościami rolnymi Skarbu Państwa, ograniczenia obszarowe przy sprzedaży

\footnotetext{
${ }^{20}$ Raport z działalności Agencji Własności Rolnej Skarbu Państwa w 2000 r., AWRSP, Warszawa 2000, s. 42-43.

${ }^{21}$ Ustawa z dnia 11 kwietnia 2003 r. o kształtowaniu ustroju rolnego., Dz.U. z 2003 r. nr 64, poz. 592.
} 
gruntów z Agencji do 500 ha użytków rolnych dla jednego podmiotu. Natomiast obszar ponad tak wyznaczony limit mógł pozostać w dalszym ciągu przedmiotem dzierżawy. W swoich założeniach Agencję Nieruchomości Rolnych ${ }^{22}$ jako następcę prawnego Agencji Własności Rolnej Skarbu Państwa zobowiązano do przestrzegania zasad sformułowanych w ustawie kształtowania ustroju rolnego państwa, które miały służyć m.in. poprawie struktury obszarowej gospodarstw rolnych, przeciwdziałaniu nadmiernej koncentracji nieruchomości rolnych oraz zapewnić prowadzenie działalności rolniczej przez osoby posiadające odpowiednie kwalifikacje. Zgodnie zapisami w art. 23. Konstytucji Rzeczypospolitej Polskiej z dnia 2 kwietnia $1997 \mathrm{r}^{23}$, podstawą ustroju rolnego państwa jest gospodarstwo rodzinne, którym w rozumieniu ustawy o kształtowaniu ustroju rolne$\mathrm{go}^{24}$ jest gospodarstwo rolne o powierzchni użytków rolnych (własnych i dzierżawionych) nieprzekraczającej 300 ha, prowadzone przez rolnika indywidualnego zamieszkałego w gminie, na obszarze której położona jest jedna z nieruchomości rolnych wchodzących w skład tego gospodarstwa, posiadającego kwalifikacje rolnicze i co najmniej 5-letnie doświadczenie w pracy w gospodarstwie rolnym.

Trzeci okres gospodarowania nieruchomościami rolnymi Skarbu Państwa (od 2004 do 16 września 2011 roku) charakteryzował się zwiększonym popytem na zakup ziemi, przy jednocześnie zmniejszającej się ofercie gruntów do zagospodarowania z Zasobu WRSP. Roczna sprzedaż gruntów kształtowała się na poziomie około 100 tys. ha, przy czym rosnącemu popytowi towarzyszyła wysoka dynamika wzrostu cen sprzedaży gruntów rolnych (z 3,7 tys. zł notowanego w 2003 roku do 17,2 tys. za

${ }^{22}$ Zgodnie z art. 18. 1. ustawy z dnia 11 kwietnia 2003 r. o kształtowaniu ustroju rolnego, Agencja Nieruchomości Rolnych stała się następcą prawnym Agencji Własności Rolnej Skarbu Państwa, Dz.U. z 2003 r. nr 64, poz. 592.

${ }^{23}$ Konstytucja Rzeczypospolitej Polskiej z dnia 2 kwietnia 1997 r., na podstawie Dz.U. z 1997 r. nr 78, poz. 483; z 2001 r. nr 28, poz. 319; z 2006 r. nr 200, poz. 1471; z 2009 r. nr 114, poz. 946.

${ }^{24}$ Artykuł 5, art. 6 i art. 7 ustawy o kształtowaniu ustroju rolnego z dnia 11 kwietnia 2003 r. (Dz.U. z 2003 r. nr 64, poz. 592). 
1 ha w 2011 roku - rysunek 2) oraz poziomu czynszów za dzierżawione grunty (z 3,7 tys. zł notowanego w 2003 roku do 192 zł za 1 ha do 723 zł za ha w 2011 roku - rysunek 2). Zmiany te zostały spowodowane m.in. wejściem Polski do Unii Europejskiej i objęciem rolników w Polsce wsparciem (dopłatami) w ramach Wspólnej Polityki Rolnej Unii Europejskiej. Grunty rolne zaczęły być postrzegane przez rolników jako swoistego rodzaju kapitał przysparzający dodatkowy dochód użytkownikowi i postrzegany jako znacznie lepsza lokata, dająca stabilny wzrost zainwestowanych środków w zakup gruntów oraz uzyskiwanych dopłat. Wysokość uzyskiwanych dopłat relatywnie szybko stała się jednym z głównych parametrów kształtujących poziomu czynszów za dzierżawione grunty rolne.

Czwarty okres (od 16 września 2011 roku do końca III kwartału 2015 roku) związany był z wprowadzeniem zmian w ustawie o gospodarowaniu nieruchomościami rolnymi ${ }^{25}$, które sprawiły, że w procesie gospodarowania Zasobem dokonano zasadniczej zmiany w podejściu do zadań realizowanych przez Agencję Nieruchomości Rolnych. Zmiany dokonane w regulacjach wymuszały niejako działania zmierzające do trwałego zagospodarowania posiadanych nieruchomości. W tym kontekście dzierżawę gruntów rolnych uznano, co do zasady, jako formę przejściową zagospodarowania, przyznając jednocześnie pierwszeństwo sprzedaży. Sprzedaż gruntów z Zasobu kształtowała się w tym okresie na poziomie od 120 do 150 tys. ha rocznie. Na przyspieszenie podjęcia decyzji o nabyciu już dzierżawionych nieruchomości rolnych Skarbu Państwa wpływ miały obawy rolników wynikające z perspektywy kończącego się 12-letniego okresu przejściowego ograniczającego zakup nieruchomości rolnych i leśnych przez cudzoziemców po wejściu Polski do Unii Europejskiej ${ }^{26}$.

${ }^{25}$ Ustawa z dnia 16 września 2011 r. o zmianie ustawy o gospodarowaniu nieruchomościami rolnymi SP oraz o zm. niektórych innych ustaw, Dz.U. z 2011 r. nr 233, poz. 1382.

${ }^{26}$ Artykuł 8 ustawy z dnia 24 marca 1920 r. o nabywaniu nieruchomości przez cudzoziemców, Dz.U. z 2004 r. nr 167, poz. 1758, z późn. zm. 
Natomiast w celu realizacji zasad zawartych w ustawie o kształtowaniu ustroju rolnego ${ }^{27}$ oraz zgodnie z postanowieniami znowelizowanej ustawy o gospodarowaniu nieruchomościami rolnymi Skarbu Państwa, do zawartych umów dzierżawy wprowadzono dodatkowe postanowienia, zgodnie z którymi Agencja w ciągu 6 miesięcy przedstawiła dzierżawcom w formie pisemnej propozycję dotyczącą wyłączenia z dzierżawy 30\% powierzchni użytków rolnych. W terminie 3 miesięcy od otrzymania zawiadomienia dzierżawca zobowiązany został do podjęcia decyzji i złożenia stosownego oświadczenia o ich przyjęciu lub odrzuceniu. Jako konsekwencję braku reakcji lub odrzuceniu zmian, dzierżawca z mocy prawa tracił prawo pierwokupu do dzierżawionych nieruchomości. Postanowienia te stosowano do umów dzierżawy zawartych po wejściu w życie ustawy z dnia 16 września 2011 r. o zmianie ustawy o gospodarowaniu nieruchomościami rolnymi Skarbu Państwa ${ }^{28}$ w sytuacji, gdy łączna powierzchnia użytków rolnych dzierżawionych z Zasobu Własności Rolnej Skarbu po dokonaniu wyłączenia nie przekraczała 300 ha. W tym zakresie pojawiały się wątpliwości, co do zgodności z przepisami Kodeksu cywilnego ${ }^{29}$ i Konstytucji

${ }^{27}$ Ustawa z dnia 11 kwietnia 2003 r. o kształtowaniu ustroju rolnego, Dz.U. z 2012 r., poz. 803.

${ }^{28}$ Ustawa z dnia 16 września 2011 r. o zmianie ustawy o gospodarowaniu nieruchomościami rolnymi SP oraz o zmianie niektórych innych ustaw - Dz.U. z 2011 r. nr 233, poz. 1382.

${ }^{29}$ Kwestie prawa pierwokupu uregulowano w Kodeksie cywilnym w Rozdziale IV. Prawo pierwokupu zgodnie z zapisami zawartymi m.in. w art. 598. Obowiązek zawiadomienia uprawnionego o treści zawartej umowy §1. Zobowiązany z tytułu prawa pierwokupu powinien niezwłocznie zawiadomić uprawnionego o treści umowy sprzedaży zawartej z osobą trzecią. §2. Prawo pierwokupu co do nieruchomości można wykonać w ciągu miesiąca, a co do innych rzeczy - w ciągu tygodnia od otrzymania zawiadomienia o sprzedaży, chyba że zostały zastrzeżone inne terminy, art. 599. Skutki naruszenia obowiązków §1. Jeżeli zobowiązany z tytułu prawa pierwokupu sprzedał rzecz osobie trzeciej bezwarunkowo albo jeżeli nie zawiadomił uprawnionego o sprzedaży lub podał mu do wiadomości istotne postanowienia umowy sprzedaży niezgodnie z rzeczywistością, ponosi on odpowiedzialność za wynikłą stąd szkodę. § 2. Jednakże jeżeli prawo pierwokupu przysługuje z mocy ustawy Skarbowi Państwa lub jednostce samorządu 
Rzeczypospolitej Polskiej ${ }^{30}$, ze względu na ograniczenie lub pozbawienie obywatela (dzierżawcy) praw nabytych. Ponadto w tym okresie, Agencji Nieruchomości Rolnych przypisano uprawnienia umożliwiające dokonywanie działań kontrolnych (w imieniu państwa) na rynku nieruchomości rolnych oraz, w razie konieczności - interweniowanie przy wykorzystaniu prawa pierwokupu (Kodeks cywilny, art. 599), co w praktyce oznacza, że Agencja mogła zdecydować o sposobie i trybie rozdysponowania nabytych tą drogą gruntów. W okresie tym w dalszym ciągu utrzymywał się systematyczny wzrost cen sprzedaży gruntów, średnio z poziomu 19,3 tys. zł w 2012 roku do 29,2 tys. zł w 2015 roku za 1 ha. Natomiast w przypadku poziomu czynszów dzierżawnych za grunty rolne można zauważyć swoistą stabilizację na wysokim poziomie w granicach od 722 zł do 822 złotych za 1 ha.

Piąty okres (od 1 maja 2016 do 2021) związany jest natomiast z kończącym się 12-letnim okresem przejściowym ograniczającym zakup nieruchomości rolnych i leśnych przez cudzoziemców ${ }^{31}$. Efektem wyrażanych

terytorialnego, współwłaścicielowi albo dzierżawcy, sprzedaż dokonana bezwarunkowo jest nieważna. Ustawa z dnia 23 kwietnia 1964 r. - Kodeks cywilny, Dz.U. z 1964 r., nr 16, poz. 93 z późn. zm.

${ }^{30}$ Kwestie te uregulowano w Rozdziale II Wolności, Prawa i Obowiązki Człowieka i Obywatela w art. 32. 1. Wszyscy są wobec prawa równi. Wszyscy mają prawo do równego traktowania przez władze publiczne. 2. Nikt nie może być dyskryminowany w życiu politycznym, społecznym lub gospodarczym z jakiejkolwiek przyczyny. Z kolei zapisy zawarte w I Rozdziale Konstytucji RP dopuszczają zgodnie z art. 22. Ograniczenie wolności działalności gospodarczej jest dopuszczalne tylko w drodze ustawy i tylko ze względu na ważny interes publiczny Konstytucja Rzeczypospolitej Polskiej z dnia 2 kwietnia 1997 r. tj. na podstawie Dz.U. z 1997 r. nr 78, poz. 483 z późn. zm.

${ }^{31} \mathrm{~W}$ art. 8 ust. 2 uregulowano nabywanie nieruchomości przez cudzoziemców, które odzwierciedlają postanowienia Traktatu o przystąpieniu Polski do Unii Europejskiej, którzy są obywatelami lub przedsiębiorcami państw członkowskich Europejskiego Obszaru Gospodarczego albo Konfederacji Szwajcarskiej, z wyjątkiem nabycia nieruchomości rolnych i leśnych przez okres 12 lat od dnia przystąpienia Polski do Unii Europejskiej. W Polsce 12-letni okres przejściowy dotyczący nabywania nieruchomości rolnych i leśnych termin upłynął 1 maja 2016 roku. Ustawa 
obaw przed niekontrolowanym nabywaniem przez nich gruntów rolnych, było uchwalenie ustawy o kształtowaniu ustroju rolnego z dnia 5 sierpnia 2015 r. ${ }^{32}$, zmieniającą ustawę z dnia 11 kwietnia 2003 r. o kształtowaniu ustroju rolnego ${ }^{33}$. W dniu 16 grudnia 2015 roku uchwalono także zmiany w ustawie o kształtowaniu ustroju rolnego ${ }^{34}$, zmieniając termin jej wejścia w życie na dzień 1 maja 2016 roku. Natomiast zgodnie z zapisami ustawy z dnia 14 kwietnia 2016 r. o wstrzymaniu sprzedaży nieruchomości Zasobu Własności Rolnej Skarbu Państwa oraz o zmianie niektórych ustaw $^{35}$, ustawy: z dnia 5 sierpnia 2015 r. o kształtowaniu ustroju rolnego i z 16 grudnia 2015 r. zostały uchylone.

Po wejściu w życie ustawy o kształtowaniu ustroju rolnego z dnia 5 sierpnia 2015 r., a następnie z dnia 14 kwietnia 2016 r. o wstrzymaniu sprzedaży nieruchomości Zasobu Własności Rolnej Skarbu Państwa, wzmocniono rolę Agencji Nieruchomości Rolnych w zakresie obrotu nieruchomościami rolnymi. Ustawa wprowadziła istotne zmiany w podejściu do obrotu gruntami rolnymi, i to nie tylko w wymiarze nieruchomości państwowych, ale przede wszystkim nieruchomości prywatnych. Zgodnie z zapisami art. 1. tej ustawy, wstrzymano sprzedaż nieruchomości albo ich części wchodzących w skład Zasobu Własności Rolnej Skarbu Państwa na 5 lat od dnia wejścia w życie ustawy, a dzierżawa będzie w tym okresie podstawową formą udostępniania państwowych gruntów rolnych. Nowelizacja określiła, że nabywcą nieruchomości rolnej może

z dnia 24 marca 1920 r. o nabywaniu nieruchomości przez cudzoziemców, Dz.U. z 1920 r. nr 31 poz. 178.

${ }^{32}$ Ustawa z dnia 5 sierpnia 2015 r. o kształtowaniu ustroju rolnego, Dz.U. z 2015 r., poz. 1433 - niniejszą ustawą planowano zmienić m.in: ustawę z dnia 23 kwietnia 1964 r. - Kodeks cywilny, ustawę z dnia 6 lipca 1982 r. o księgach wieczystych i hipotece; ustawę z dnia 17 maja 1989 r. - prawo geodezyjne i kartograficzne; ustawę z dnia 19 października 1991 r. o gospodarowaniu nieruchomościami rolnymi Skarbu Państwa. Ustawa ta jednak nie weszła w życie.

${ }^{33}$ Ustawa z dnia 11 kwietnia 2003 r. o kształtowaniu ustroju rolnego, Dz.U. z 2012 r., poz. 803.

${ }^{34}$ Dz.U. z 2015 r., poz. 2179.

${ }^{35}$ Dz.U. z 2016 r., poz. 585. 
być jedynie rolnik indywidualny, czyli osoba fizyczna, posiadająca kwalifikacje rolnicze, zamieszkała na terytorium gminy - miejsca położenia nieruchomości i prowadząca osobiście gospodarstwo rolne. Ponadto nowe przepisy spowodowały, że nabywca nieruchomości rolnej miał istotne ograniczenia w zakresie wykonywania prawa własności nieruchomości, w szczególności, że w okresie co najmniej 10 lat od dnia nabycia, był zobowiązany do prowadzenia gospodarstwa rolnego, w skład którego weszła nabywana nieruchomość. Ponadto w tym okresie nie miał możliwości zbywania nieruchomości i przekazywania jej innym podmiotom (w dzierżawę, najem itp.).

W efekcie wprowadzonych regulacji od 1 maja 2016 roku grunty rolne nie mogły być nabywane dla innych celów niż prowadzenie gospodarstwa rolnego, co spowodowało mniejsze zainteresowanie nabywaniem gruntów SP, mimo potencjalnych możliwości spadku cen ze względu na wprowadzone ograniczenia ${ }^{36}$. Z dniem 26 czerwca 2019 r. weszła w życie ustawa z dnia 26 kwietnia 2019 roku o zmianie ustawy o kształtowaniu ustroju rolnego oraz niektórych innych ustaw ${ }^{37}$. Zgodnie z jej zapisami zmieniono ograniczenie co do swobodnego obrotu ziemią z dotychczas obowiązującej powierzchni 0,3 ha do 1 ha oraz skrócono okres możliwości sprzedaży nabytych gruntów rolnych po 5 latach (uprzednio po 10 latach).

${ }^{36}$ W kwestii ograniczeń w zakresie obrotu gruntami rolnymi Trybunału Sprawiedliwości Unii Europejskiej wydał komunikat wyjaśniający Komisji w sprawie nabywania gruntów rolnych i prawa Unii Europejskiej (2017/C 350/05). Wynika z niego, że zgodnie z prawem Unii państwa członkowskie mogą uwzględniać uzasadnione obawy w zakresie polityki. Mogą one określać odpowiednią politykę w zakresie swoich rynków gruntów rolnych. Trybunał uznał liczne cele polityki rolnej, które mogą stanowić uzasadnienie ograniczeń podstawowych wolności. Głównym warunkiem jest jednak wyraźne określenie celów i wybór instrumentów proporcjonalnych do realizacji tych celów, tj. takich, które nie wykraczają poza to, co jest konieczne, i nie są dyskryminujące.

${ }^{37}$ Dz.U. z 2019 r., poz. 1080. 


\subsection{Dzierżawa jako instrument gospodarowania Zasobem Własności Rolnej Skarbu Państwa}

Wejście w życie w dniu 30 kwietnia 2016 roku ustawy o wstrzymaniu sprzedaży nieruchomości Zasobu Własności Rolnej Skarbu Państwa oraz o zmianie niektórych ustaw, zmieniło zasady gospodarowania mieniem. Podstawową formą zagospodarowania państwowych gruntów od 1 maja 2016 roku stała się dzierżawa, którą w pierwszej kolejności KOWR ma obowiązek oferować w trybie przetargu ograniczonego (licytacja lub oferta pisemna) wyłącznie dla rolników indywidualnych zamierzających powiększyć lub utworzyć gospodarstwo rodzinne. Co do zasady, w przyjętych założeniach, wysokość czynszu nie jest decydującym kryterium wyłaniania zwycięzcy. Natomiast od 20 sierpnia 2016 roku wysokość czynszu dzierżawnego za 1 hektar gruntu w danej klasie bonitacyjnej, położonego w określonym okręgu podatkowym regulowana jest rozporządzeniem Ministra Rolnictwa i Rozwoju Wsi z 1 sierpnia 2016 roku w sprawie sposobu ustalania wysokości czynszu dzierżawnego w umowach dzierżawy nieruchomości Zasobu Własności Rolnej Skarbu Państwa ${ }^{38}$. Obliczony zgodnie z rozporządzeniem czynsz dzierżawny określa wartość czynszu wywoławczego do licytacji w przetargach, jak i wysokość czynszu płaconego przez wyłonionego dzierżawcę w drodze przetargu ograniczonego ofertowego (czynsz w przetargu ograniczonym ofertowym płacony KOWR jest stały i nie stanowi kryterium oceny ofert). Zasady dzierżawy nieruchomości Zasobu Własności Rolnej Skarbu Państwa regulują obecnie przepisy kodeksu cywilnego ${ }^{39}$ oraz m.in. zarządzenia Dyrektora Generalnego Krajowego Ośrodka Wsparcia Rolnictwa dotyczące gospodarowania Zasobem Własności Rolnej Skarbu Państwa. Z kolei w przypadku przedłużenia umowy dzierżawy z dotychczasowym dzierżawcą istnieje możliwość, zgodnie z art. 39 ustawy z dnia 19 października1991 r. o gospodarowaniu nieruchomościami

38 Dz.U. z 2016 r., poz. 1186.

${ }^{39}$ Dz.U. z 1964 r. nr 16, poz. 93 (t.j. Dz.U. z 2019 r., poz. 1145, 1495.). 
rolnymi Skarbu Państwa ${ }^{40}$, stosowania procedury bezprzetargowej. Przetargu nie stosuje się w sytuacji, jeżeli dotychczasowy dzierżawca złożył oświadczenie o zamiarze dalszego dzierżawienia nieruchomości na nowych uzgodnionych warunkach z KOWR, przy czym czynsz nie może być niższy niż dotychczasowy. W procedurze przedłużania dzierżawy wprowadzono stosowne preferencje korespondujące z obowiązującą polityką państwa w zakresie rozwoju gospodarstw rodzinnych. Co do zasady umowy dzierżawy zawarte z rolnikami indywidualnymi, w rozumieniu ustawy o kształtowaniu ustroju rolnego, mogą być zawierane na okres do 15 lat, jeśli osoba prowadzi gospodarstwo rodzinne w rozumieniu przepisów o kształtowaniu ustroju rolnego, albo jej wiek nie przekracza 40 lat. Umowy dzierżawy zawarte z innymi podmiotami niż rolnicy indywidualni w myśl przyjętych zasad mogą być wydłużane do 8 lat ${ }^{41}$. Wydłużanie umów na wskazane wyżej okresy stanowi generalną zasadę przy rozpatrywaniu przez KOWR wniosków dzierżawców. Jednakże mając na uwadze specyfikę działalności rolniczej i uwarunkowania formalnoprawne, gospodarcze i organizacyjne sprawia, że wydłużenie umowy na wymieniony okres może być niewystarczające. Dlatego też, w uzasadnionych przypadkach, za uprzednią zgodą Dyrektora Generalnego KOWR, wydłużenie umowy może nastąpić na dłuższy okres.

W Zasobie WRSP, według stanu na koniec 2018 roku, ze znajdujących się ogółem 1368,9 tys. ha około 3/4 pozostawało w dzierżawie (1,02 mln ha), z czego większość jest położona głównie na obszarze północnej i północno-zachodniej części Polski. Zmiany - zarówno w poziomie, jak i strukturze zagospodarowania Zasobu - są głównie odzwierciedleniem dokonujących się zmian sytuacji społeczno-gospodarczej, rynkowej - związanej z popytem i podażą gruntów czy politycznej - związanej z kształtowaniem ustroju rolnego. Analizując wielkość Zasobu WRSP, jego strukturę i dynamikę zmian form zagospodarowania w latach 1992-2018 można stwierdzić, że dzierżawa była podstawową formą zagospodarowania

\footnotetext{
${ }^{40}$ Dz.U. z 2016 r., poz. 1491 z późn. zm.

${ }^{41}$ Zarządzenie Dyrektora Generalnego KOWR nr 95/2017/Z.
} 
przejętych gruntów. Dla większości dzierżawców umożliwiła i stała się niejako podstawą do podjęcia decyzji o ich wykupie na własność. Największy obszar gruntów rolnych będących w dzierżawie zanotowano w 1996 i kształtował się na poziomie ponad 2,9 mln ha, co stanowiło około 2/3 Zasobu WRSP.

Od 2016 roku systematycznie zmniejszała się powierzchnia gruntów dzierżawionych, co głównie było związane z procesem ich nabywania przez dotychczasowych dzierżawców. Cechą charakterystyczną umów dzierżawy gruntów rolnych jest okresowy charakter użytkowania, który zakłada możliwość ich rotacji po wygaśnięciu umów, rozwiązaniu umów, czy też wyłączenia części obszaru. Najczęściej zwroty w analizowanym okresie dokonywane były ze względu na trudną sytuację ekonomiczno-finansową dzierżawcy, a także rozwiązanie umowy lub wyłączenie części gruntów z dzierżawy w celu sprzedaży dotychczasowemu dzierżawcy, dzierżawy/ sprzedaży innemu dzierżawcy lub przeznaczenie na realizację innych zadań (wykres 10.1. i rysunek 10.2.).

Zaobserwowany brak stabilności rozwiązań formalnoprawnych związanych z wprowadzaniem ograniczeń wpływa na swobodę decyzyjną rolników odnośnie do zakresu i możliwości kształtowania wielkości gospodarstwa, a także skali produkcji. W swej istocie działalność rolników powinna sprowadzać się do racjonalnego gospodarowania posiadanymi zasobami umożliwiającymi opłacalną produkcję, a tej z kolei nie sprzyja tymczasowość wprowadzanych ograniczeń oraz niepewność odnośnie do przyszłych rozwiązań w zakresie obrotu gruntami rolnymi wynikających z polityki rolnej ${ }^{42}$.

42 J. Mioduszewski, R. Przygodzka, A. Sadowski, Conditions of development of arable land belonging to State Treasury in warminsko-mazurskie region, Proceedings of the 2018 International Conference "Economic Science for Rural Development" nr 47 Jelgava, LLU ESAF, 911 May 2018, s. 213-220. 


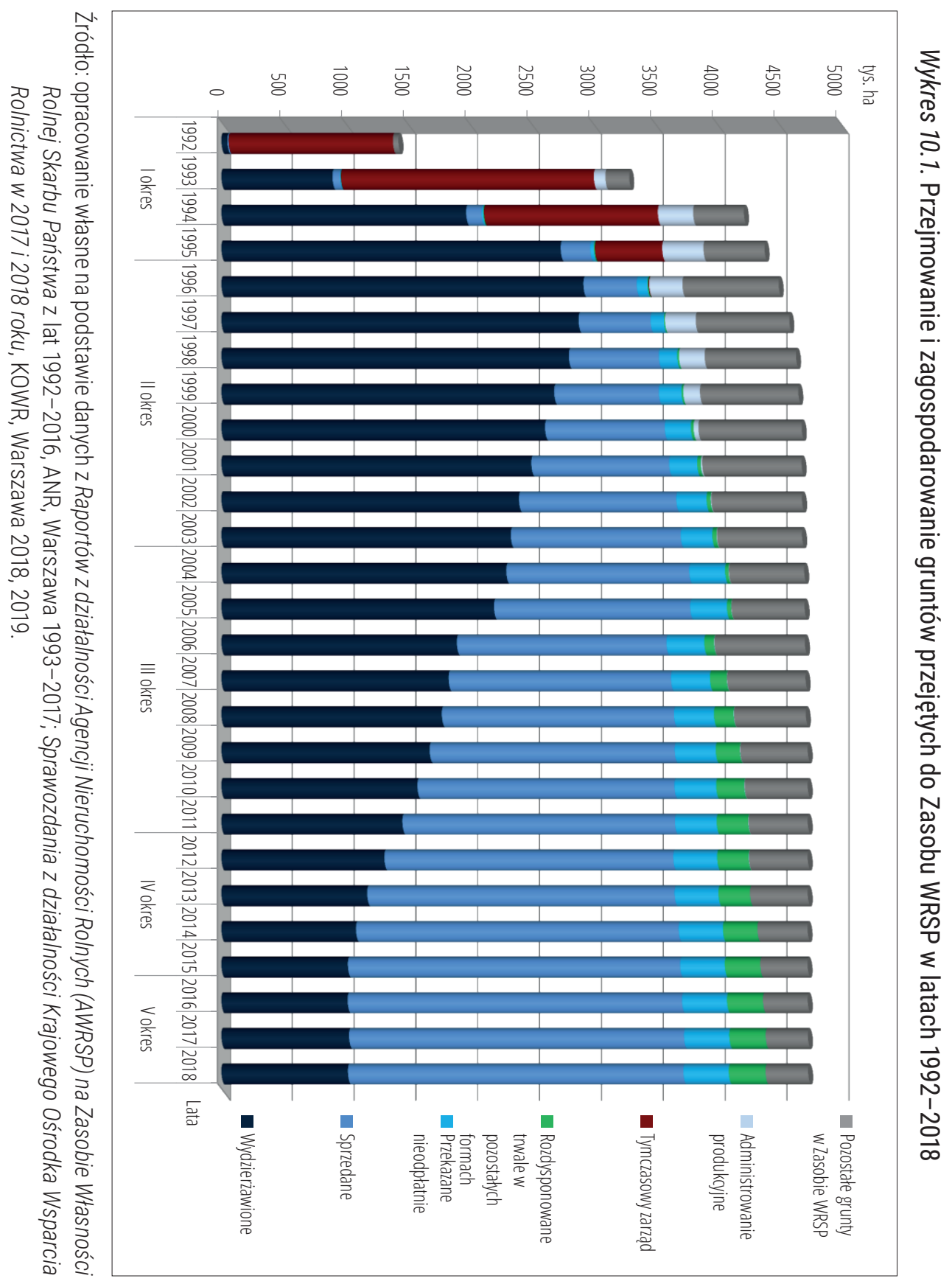


Rysunek 10.2. Powierzchnia gruntów w Zasobie WRSP pozostająca w dzierżawie w podziale na województwa, według stanu na 31 grudnia 2018 roku

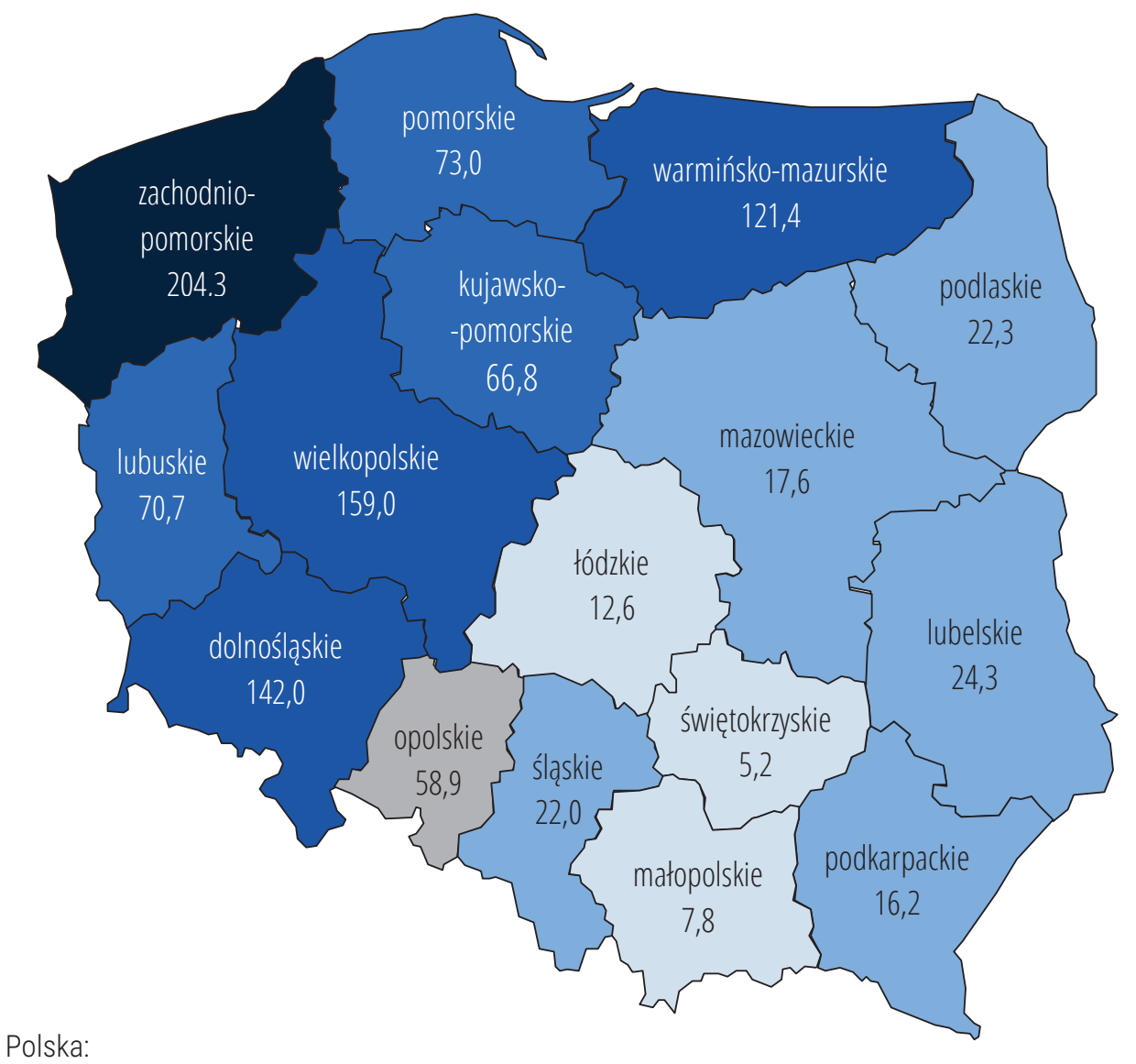

4744,03 tys. ha - grunty przejęte do Zasobu WRSP

1024,1 tys. ha $(21,6 \%)$ - grunty dzierżawione z Zasobu WRSP

Źródło: opracowanie własne na podstawie danych ze Sprawozdania z działalności Krajowego Ośrodka Wsparcia Rolnictwa w 2018 roku, KOWR, Warszawa 2019, s. 217.

Analizując liczbę zawartych umów dzierżawnych i powierzchnię obecnie dzierżawionych gruntów można zauważyć duże zróżnicowanie, ponieważ według stanu na koniec 2018 roku z Zasobu wydzierżawiono 1024,1 tys. ha na podstawie 60412 umów, z tego 2,7\% dotyczyło obszaru o powierzchni powyżej 100 ha, które stanowiły w strukturze dzierżaw 57\%. 
Tabela 10.1. Powierzchnia i struktura gruntów wydzierżawionych z Zasobu WRSP według grup obszarowych (stan na koniec 2018 roku)

\begin{tabular}{|c|c|c|c|c|c|c|c|c|c|c|c|c|c|}
\hline \multirow{3}{*}{$\begin{array}{l}\text { Zakres } \\
\text { powierzchni } \\
\text { gruntów } \\
\text { w umowie }\end{array}$} & \multirow{3}{*}{ 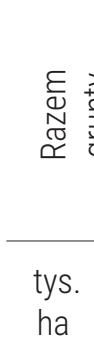 } & \multirow{3}{*}{ 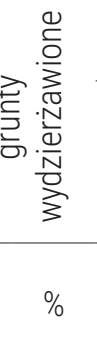 } & \multicolumn{4}{|c|}{ Powierzchnia gruntów } & \multirow{2}{*}{\multicolumn{2}{|c|}{ 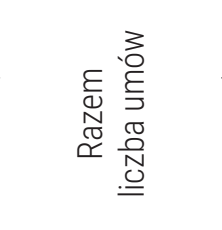 }} & \multicolumn{4}{|c|}{ Liczba umów } & \multirow{3}{*}{ 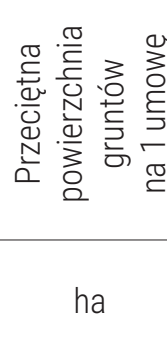 } \\
\hline & & & \multicolumn{2}{|c|}{$\begin{array}{c}\text { osoby } \\
\text { fizyczne }\end{array}$} & \multicolumn{2}{|c|}{$\begin{array}{l}\text { osoby } \\
\text { prawne } \\
\text { i inne }\end{array}$} & & & \multicolumn{2}{|c|}{$\begin{array}{c}\text { osoby } \\
\text { fizyczne }\end{array}$} & \multicolumn{2}{|c|}{$\begin{array}{c}\text { osoby } \\
\text { prawne } \\
\text { i inne }\end{array}$} & \\
\hline & & & $\begin{array}{l}\text { tys. } \\
\text { ha }\end{array}$ & $\%$ & $\begin{array}{l}\text { tys. } \\
\text { ha }\end{array}$ & $\%$ & $\begin{array}{l}\text { liczba } \\
\text { umów }\end{array}$ & $\%$ & $\begin{array}{l}\text { liczba } \\
\text { umów }\end{array}$ & $\%$ & $\begin{array}{l}\text { liczba } \\
\text { umów }\end{array}$ & $\%$ & \\
\hline do 0,99 & 8,5 & 0,8 & 8,4 & 0,8 & 0,1 & 0,0 & 17933 & 29,7 & 17645 & 29,2 & 288,0 & 0,5 & 0,5 \\
\hline $\begin{array}{l}\text { od } 1,0 \\
\text { do } 1,99\end{array}$ & 13,4 & 1,3 & 13,2 & 1,3 & 0,2 & 0,0 & 9414 & 15,6 & 9280 & 15,4 & 134,0 & 0,2 & 1,4 \\
\hline $\begin{array}{l}\text { od 2,0 } \\
\text { do } 4,99\end{array}$ & 35,9 & 3,5 & 35,1 & 3,4 & 0,8 & 0,1 & 11289 & 18,7 & 11085 & 18,3 & 204,0 & 0,3 & 3,2 \\
\hline $\begin{array}{l}\text { od 5,0 } \\
\text { do } 9,99\end{array}$ & 49,7 & 4,9 & 48,6 & 4,7 & 1,2 & 0,1 & 6918 & 11,5 & 6754 & 11,2 & 164,0 & 0,3 & 7,2 \\
\hline $\begin{array}{l}\text { od } 10,0 \\
\text { do } 19,99\end{array}$ & 101,4 & 9,9 & 99,2 & 9,7 & 2,2 & 0,2 & 7099 & 11,8 & 6948 & 11,5 & 151,0 & 0,2 & 14,3 \\
\hline $\begin{array}{l}\text { od } 20,0 \\
\text { do } 49,99\end{array}$ & 142,9 & 14,0 & 135,1 & 13,2 & 7,8 & 0,8 & 4826 & 8,0 & 4583 & 7,6 & 243,0 & 0,4 & 29,6 \\
\hline $\begin{array}{l}\text { od } 50 \\
\text { do } 99,99\end{array}$ & 88,6 & 8,6 & 74,6 & 7,3 & 13,9 & 1,4 & 1277 & 2,1 & 1086 & 1,8 & 191,0 & 0,3 & 69,4 \\
\hline $\begin{array}{l}\text { od } 100,0 \\
\text { do } 299,99\end{array}$ & 188,4 & 18,4 & 113,6 & 11,1 & 74,9 & 7,3 & 1074 & 1,8 & 668 & 1,1 & 406,0 & 0,7 & 175,5 \\
\hline $\begin{array}{l}\text { od } 300,0 \\
\text { do } 499,99\end{array}$ & 144,0 & 14,1 & 54,4 & 5,3 & 89,6 & 8,7 & 378 & 0,6 & 146 & 0,2 & 232,0 & 0,4 & 380,9 \\
\hline $\begin{array}{l}\text { od } 500,0 \\
\text { do } 999,99\end{array}$ & 85,7 & 8,4 & 11,7 & 1,1 & 74,0 & 7,2 & 127 & 0,2 & 18 & 0,0 & 109,0 & 0,2 & 674,9 \\
\hline $\begin{array}{l}\text { 1000,00 } \\
\text { i więcej }\end{array}$ & 165,7 & 16,2 & 2,2 & 0,2 & 163,4 & 16,0 & 77 & 0,1 & 2 & 0,0 & 75,0 & 0,1 & 2151,4 \\
\hline $\begin{array}{l}\text { Ogółem } \\
\text { grunty }\end{array}$ & 1024,1 & 100,0 & 596,0 & 58,2 & 428,0 & 41,8 & 60412 & 100,0 & 58215 & 96,4 & 2197,0 & 3,6 & 17,0 \\
\hline
\end{tabular}

w tym:

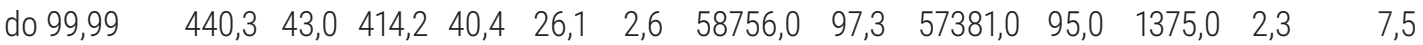

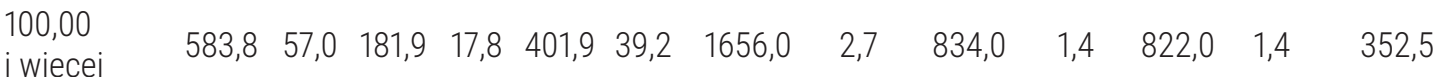

Źródło: opracowanie własne na podstawie danych ze Sprawozdania z działalności Krajowego Ośrodka Wsparcia Rolnictwa w 2018 roku, KOWR, Warszawa 2019, s. 215-216. 
Ogółem przeciętny obszar dzierżawionych gruntów na 1 zawartą umowę wynosił 17,0 ha. Charakterystyczne jest, że w przypadku 1656 zawartych umów przeciętny obszar dzierżawionych gruntów w grupie powyżej 100 ha wynosił 352,5 ha, a poniżej 100 ha kształtował się zaledwie na poziomie 7,5 ha. Zbliżoną sytuację można również zaobserwować przy sprzedaży gruntów, gdzie obszar dotyczący 3348 zawartych umów stanowił 36,4\% (ok. 950,2 tys. ha, tj. 238,8 ha na 1 umowę). Wśród dzierżawców nieruchomości dominują osoby fizyczne (96,4\% zawartych umów), którzy dzierżawią 596 tys. ha, co stanowi 58,2\% gruntów wydzierżawionych. Natomiast osoby prawne 428 tys. ha, z czego $90 \%$ tego obszaru obejmują umowy (822) na powierzchnię powyżej 100 ha (tabela 10.1.). Taki stan struktury zawartych umów na dzierżawę i sprzedaż gruntów wskazuje, że przekształcenia w państwowym sektorze rolnictwa przyczyniły się w głównej mierze do powstania gospodarstw wielkoobszarowych, a w znacznie mniejszym stopniu wpłynęły na zmianę struktury obszarowej indywidualnych gospodarstw rolnych.

Na trwałość zawartych umów na dzierżawę gruntów rolnych ma wpływ, oprócz czynników zewnętrznych, jakość gleb, wielkość obszaru, ukształtowanie rozłogu, położenie oraz poziom płaconych czynszów dzierżawnych, który ma bezpośrednie przełożenie na opłacalność produkcji rolnej. W swej istocie poziom czynszu dzierżawnego powinien uwzględniać i równoważyć interesy stron umowy tj. wydzierżawiającemu zapewnić co najmniej minimalny dochód odpowiadający oprocentowaniu lokaty kapitałowej, a dzierżawcy wytworzenie dochodów zapewniające minimum egzystencji jemu i jego rodzinie. Jednoczesna realizacja interesów stron umowy na dzierżawę gruntów w praktyce jest trudna do osiągnięcia. W związku z tym kształtowanie wysokości czynszu dzierżawnego może stanowić istotny element ochrony decydujący o trwałości gospodarowania na dzierżawionym gruncie i podlegać prawnej regulacji ${ }^{43}$. Poziom czynszów

${ }^{43}$ A. Majchrzak, Determinanty trwałości gospodarowania na dzierżawionych gruntach rolnych $w$ Polsce na tle wybranych państw Europy Zachodniej, "Progress in Economic Sciences" 2014, nr 1, s. 21. 
uzyskiwanych za dzierżawę gruntów z Zasobu WRSP kształtował się w granicach od 1,8 dt pszenicy/1 ha w 1996 roku do 12,6 dt pszenicy/1 ha w 2016 roku. Natomiast analizując poziom czynszów w ujęciu wartościowym, można zauważyć, że od 1992 roku do 2003 roku był on relatywnie niski i kształtował się od 57 zł/1 ha do 123 zł/1 ha. Od 2004 roku do 2014 można zauważyć systematyczny wzrost poziomu czynszów dzierżawnych od $192 \mathrm{zl} / 1$ ha do $822 \mathrm{zl} / 1$. W znacznej mierze miały na to wpływ uwarunkowania zewnętrzne wynikające z perspektywy przystąpienia Polski do Unii Europejskiej i objęcia Wspólną Polityką Rolną (WPR) oraz związane z tym faktem dopłaty do działalności rolniczej. W konsekwencji stosowane instrumenty WPR, w tym głównie jednolite płatności bezpośrednie, stanowiły punkt odniesienia i przyczyniły się do wzrostu czynszów dzierżawnych. Jak wskazuje Bazyli Czyżewski i Radosław Trojanek ${ }^{44}$, dopłaty bezpośrednie nie są związane z wielkością produkcji, a w przypadku dzierżawy ich część przekazywana jest właścicielom gruntów poprzez wyższe stawki dzierżawy gruntów rolnych. W konsekwencji korzyści finansowe uzyskiwane z tytułu dopłat nie kapitalizują się w rolnictwie, gdy właściciel nie jest rolnikiem. W analizowanym okresie można zauważyć zmianę trendu wzrostowego czynszów dzierżawnych w 2009 roku, na co miał wpływ ogólnoświatowy kryzys gospodarczy wywołany brakiem stabilności na rynkach finansowych i bankowych, który związany był z zapaścią na rynku pożyczek hipotecznych wysokiego ryzyka w Stanach Zjednoczonych. Od 2015 roku ze względu na wprowadzone ograniczenia w obrocie gruntami rolnymi można zauważyć ich stopniowe obniżenie do poziomu 511 zł/1 ha w 2018 roku. Utrzymujący się relatywnie wysoki poziom uzyskiwanych czynszów dzierżawnych za grunty rolne wynikał głównie z popytu zgłaszanego ze strony rolników przy niewielkiej ich podaży, uzyskiwane dopłaty bezpośrednie z tytułu użytkowania, opłacalność produkcji rolniczej oraz

${ }^{44}$ B. Czyżewski, R. Trojanek, Czynniki wartości ziemi rolnej w kontekście zróżnicowanych funkcji obszarów wiejskich w Polsce, „Zagadnienia Ekonomiki Rolnej” 2016, nr 2(347), s. 7. 
wprowadzone ustawowe ograniczenia w obrocie gruntami rolnymi ${ }^{45}$. Analizując relacje cen sprzedaży gruntów rolnych do przeciętnego poziomu czynszu dzierżawnego płaconego za 1 ha użytkowanych gruntów można sądzić, że miały one wpływ na podejmowanie decyzji o zmianie prawa do użytkowania (dzierżawa) na prawo własności (nabycie). W badanym okresie cena nabycia gruntów kształtowała się na poziomie od 8,8-krotności za 1 ha w 1992 roku do 60,8-krotności w 2017 roku (wykres 10.2.)

Wykres 10.2. Poziom czynszów dzierżawnych i cen sprzedaży za grunty z Zasobu WRSP w latach 1992-2018

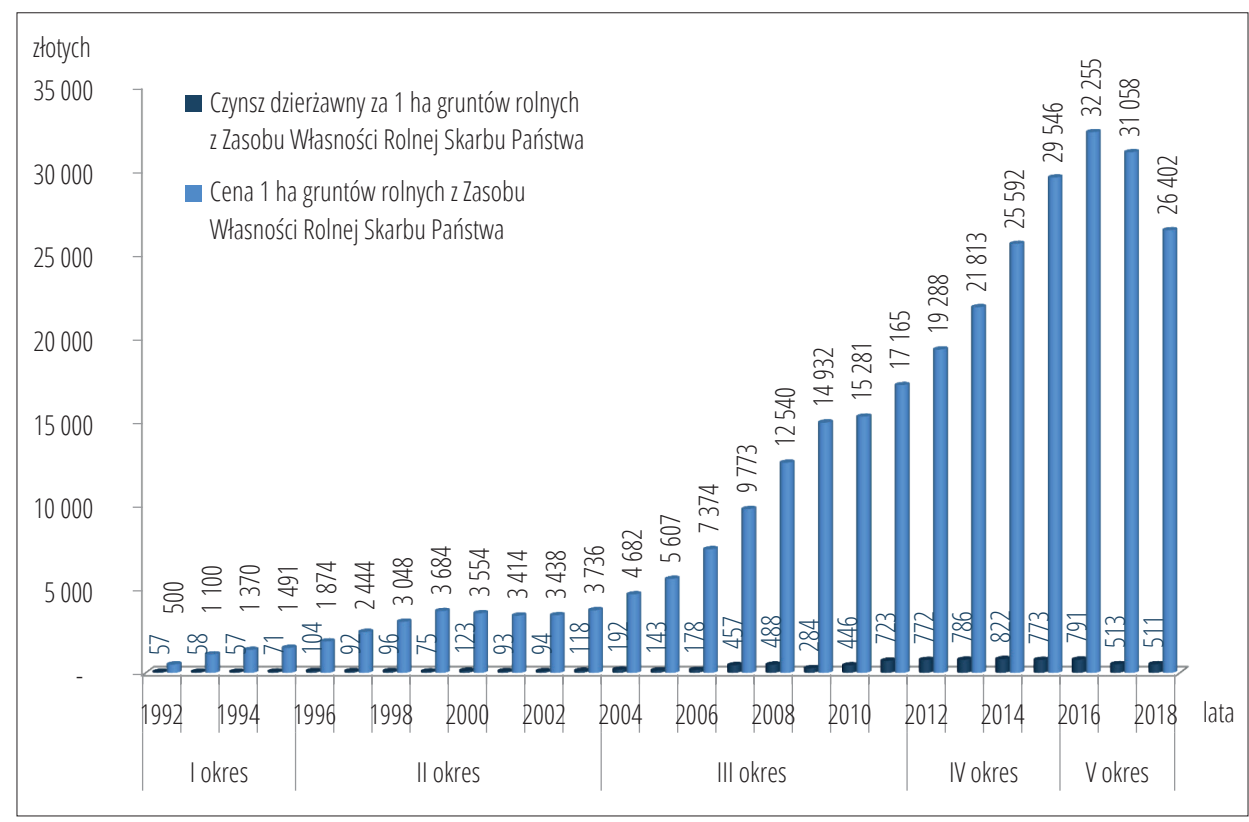

Źródło: opracowanie własne na podstawie danych z Raportów z działalności Agencji Nieruchomości Rolnych (AWRSP) na Zasobie Własności Rolnej Skarbu Państwa w latach 1992-2016, ANR, Warszawa 1993-2017; oraz Sprawozdań z działalności Krajowego Ośrodka Wsparcia Rolnictwa w 2017 i 2018, KOWR, Warszawa 2018, 2019.

${ }^{45}$ Ustawa z dnia 5 sierpnia 2015 r. o kształtowaniu ustroju rolnego (Dz.U. z 2015 r., poz. 1433 i 2179); ustawa z dnia 14 kwietnia 2016 r. o wstrzymaniu sprzedaży nieruchomości Zasobu Własności Rolnej Skarbu Państwa (Dz.U. z 2016 r., poz. 585). 
Wysoki poziom czynszu dzierżawnego, a także cen zakupu gruntów oraz perspektywa ich wzrostu dodatkowo stymulowała dzierżawców do zakupu gruntów. Ponadto dynamicznie zmieniające się uwarunkowania społeczno-gospodarcze, wzrost poziomu cen i rosnący popyt na grunty rolne, które postrzegane były nie tylko jako podstawowy zasób produkcji w rolnictwie, ale również jako inwestycja dająca satysfakcjonujący zwrot kapitału, skłaniały do podejmowania decyzji o ich zakupie (wykres 10.2. i wykres 10.3.).

Wykres 10.3. Relacja ceny sprzedaży gruntów do czynszu dzierżawnego z Zasobu WRSP w latach 1992-2018

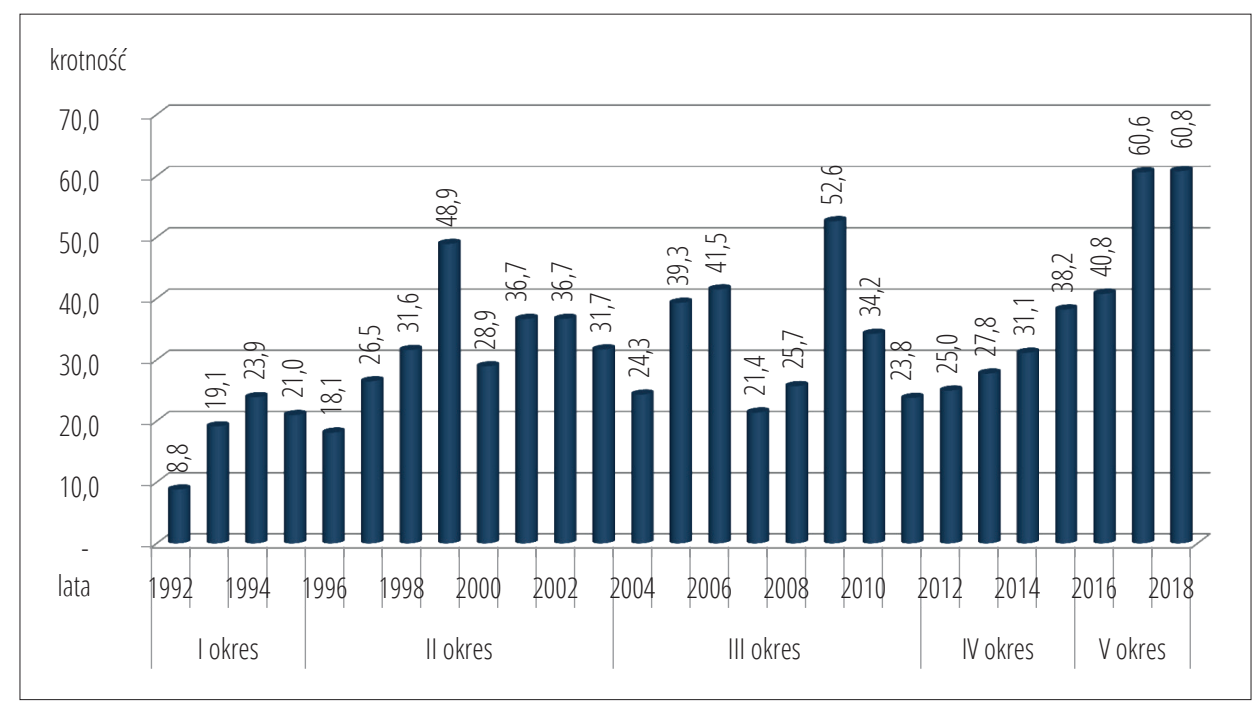

Źródło: opracowanie własne na podstawie danych z Raportów z działalności Agencji Nieruchomości Rolnych (AWRSP) na Zasobie Własności Rolnej Skarbu Państwa w latach 1992-2016, ANR, Warszawa 1993-2017; oraz Sprawozdań z działalności Krajowego Ośrodka Wsparcia Rolnictwa w 2017 i 2018, KOWR, Warszawa 2018, 2019.

Od początku przekształceń własnościowych w państwowym sektorze rolnictwa można zauważyć silną tendencję do zmniejszania się ogólnej liczby gospodarstw rolnych. W latach 1990-2018, liczba indywidualnych gospodarstw rolnych $\left(\right.$ IGR $^{46}$ ) ogółem zmniejszyła się o około 47,8\%

${ }^{46}$ Dane dotyczą indywidualnych gospodarstw rolnych powyżej 1 ha UR. 
tj. z 2137,5 tys. do 1112,7 tys. W analizowanym okresie najwięcej gospodarstw rolnych ubyło w latach 2009-2013 (ponad 654,2 tys.). Wśród grup obszarowych w tym czasie zwiększyła się tylko liczba gospodarstw powyżej 15 ha. Na koniec 2018 roku w tej grupie znajdowało się ponad 207,4 tys. gospodarstw rolnych, w tym największą grupę stanowiły te, o powierzchni od 20 do 50 ha tj. 107,9 tys. W tym okresie dynamikę ograniczania liczby gospodarstw ogółem w nieznacznym stopniu osłabiało powstawanie nowych gospodarstw rolnych tworzonych na bazie nieruchomości rolnych pochodzących z Zasobu WRSP. Zagospodarowanie tych nieruchomości przyczyniło się także do powstawania gospodarstw wielkoobszarowych. W wyniku dokonanych zmian w regulacjach formalnoprawnych dotyczących obrotu ziemią, nałożenia się procesów „wypadania” gospodarstw rolnych oraz zagospodarowania nieruchomości rolnych Skarbu Państwa powstało blisko 33 tys. gospodarstw o powierzchni powyżej 50 ha UR. W strukturze obszarowej, jak wskazuje Włodzimierz Dzun ${ }^{47}$, ukształtowała się na bazie początkowo dzierżawionych nieruchomości rolnych Skarbu Państwa nowa grupa prywatnych gospodarstw wielkoobszarowych o powierzchni powyżej 100 ha UR (ponad 4,4 tys. gospodarstw gospodarujących na 2072 tys. ha UR, z tego 35,5\% stanowią gospodarstwa powyżej 500 ha UR na 1132 tys. ha UR). W efekcie zachodzących zmian nastąpiło niejako odtworzenie prywatnej wielkiej własności ziemskiej, co w perspektywie wzrostu popytu na ziemię ze strony rolników indywidualnych w ich rejonie może być zarzewiem społecznych konfliktów. Największy ubytek gospodarstw zanotowano w grupie obszarowej od 5 do 10 ha UR (ponad 50,5\% - 321,6 tys. gospodarstw) i grupie od 2 do 5 ha 40,2\% (302,0 tys. gospodarstw). W grupach obszarowych od 1 ha do 2 ha UR o $24,7 \%$ (93,3 tys. gospodarstw) oraz w grupie od 10 do 15 ha UR o 41,4\% (100,2 tys. gospodarstw - wykres 10.4.).

${ }^{47}$ W. Dzun, Wptyw utworzenia i rozdysponowania zasobu własności rolnej SP na strukturę obszarowa gospodarstw rolnych, „Zagadnienia Ekonomiki Rolnej” 2017, nr 3(344), s. 69-70. 
드응으

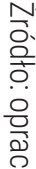
is 몰 졸

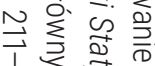
로 $\rightarrow$ 을 ก O 출. क⿺辶大

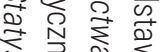

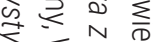

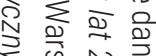

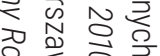
일 $\sum_{0}^{\infty} \overrightarrow{0}$ 고월 ¿ो $\overrightarrow{0}$ is $\frac{9}{0}$ $\infty$ 달

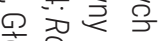

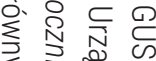
$\subseteq$ क ल

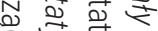

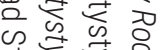

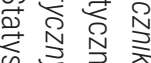

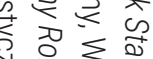

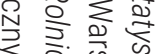

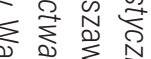
के N $\sum_{0} N$ 至

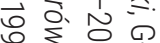

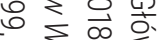

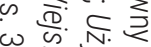

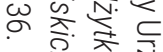
ำ 유 Q @

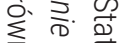
产电离

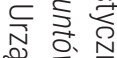
है 롤 品 के के ले ก $\sqrt{2} \sqrt{2}$ $\sum_{0}^{\infty} \stackrel{\infty}{0}$ क क क N

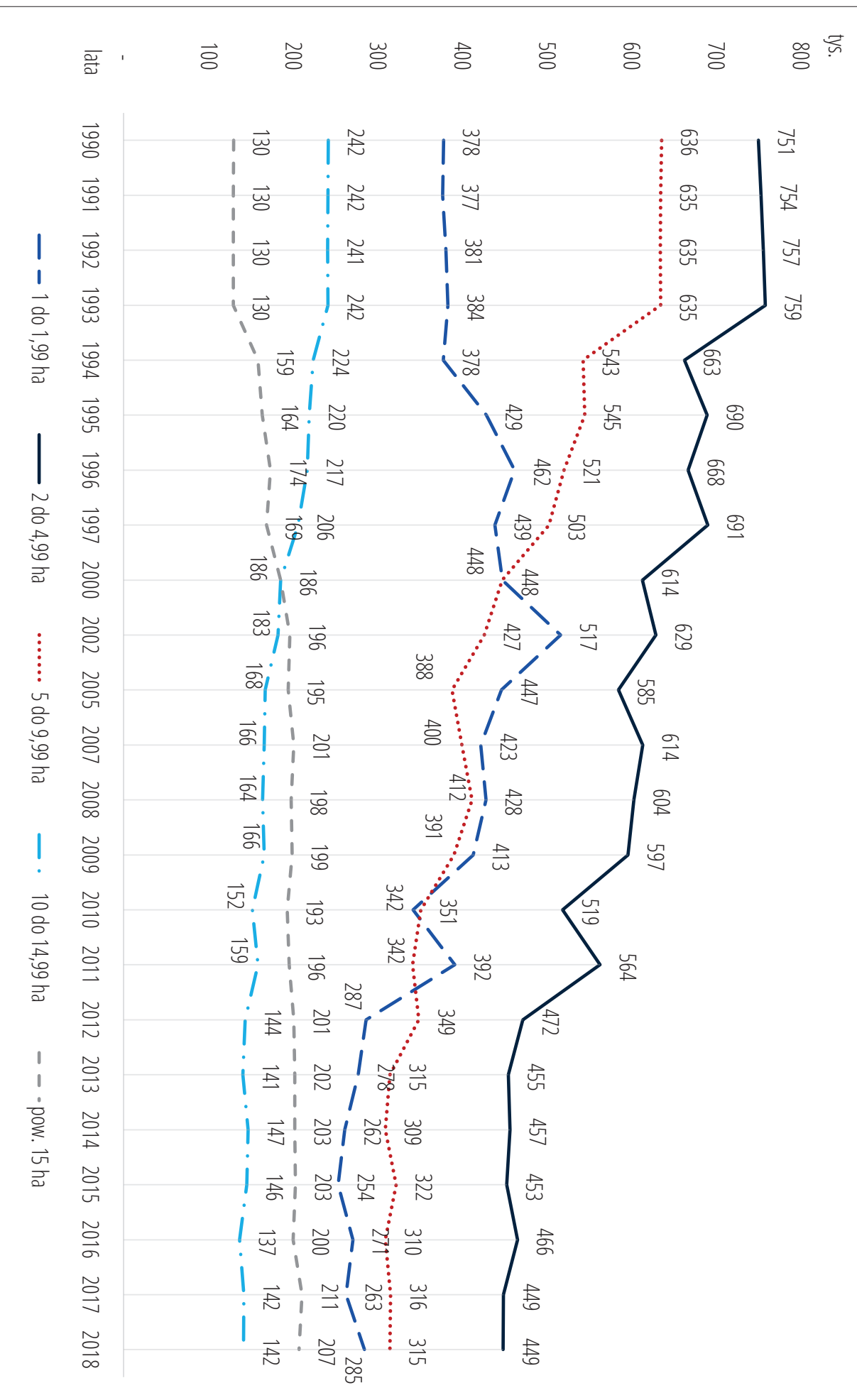


Jak wskazuje Alina Sikorska ${ }^{48}$, w omawianym okresie ostatnich 27 lat na poziom i dynamikę zmniejszania się liczby gospodarstw wpływ miały nie tylko czynniki związane z rolnictwem, ale także rozwój infrastruktury i procesy urbanizacji obszarów wiejskich wokół metropolii, co w konsekwencji skutkowało konwersją ziemi na cele nierolnicze. Ponadto istotny wpływ na zachodzące zmiany wywierały efekty Wspólnej Polityki Rolnej UE oraz środki finansowe pozyskiwane z funduszy spójności, a także przeznaczone na rozwój kapitału ludzkiego. Zmiany w strukturze obszarowej dokonały się w skali całego kraju, jednak ze względu na zróżnicowanie regionalne powiązane z historycznie ukształtowanymi przestrzennymi odmiennościami we właściwościach struktury rolnictwa, miało różne natężenie. W regionach, gdzie więcej było silnych ekonomicznie gospodarstw zamierzających zwiększyć zakres i skalę prowadzonej działalności notowano większy popyt na grunty rolne oraz wyższe ceny ziemi.

Dokonane zmiany w regulacjach formalnoprawnych zmieniły podejście do obrotu gruntami rolnymi w Polsce, zgodnie z którymi KOWR (wcześniej ANR) zobowiązano do sprawowania bezpośredniego nadzoru nad obrotem gruntami rolnymi. Na mocy ustawy z dnia 14 kwietnia 2016 r. o wstrzymaniu sprzedaży nieruchomości Zasobu Własności Rolnej Skarbu Państwa ${ }^{49}$, która obowiązuje od 1 maja 2016 roku ${ }^{50}$, wprowadzono istotne ograniczenia w obrocie gruntami rolnymi, tj. ograniczenie sprzedaży gruntów Skarbu Państwa. Ponadto uzyskał on pierwszeństwo nabycia gruntów rolnych zarówno Skarbu Państwa, jak i prywatnych. W tej sytuacji sensownym rozwiązaniem poprawy sprawności nadzoru nad obrotem gruntami rolnymi Skarbu Państwa może być koncepcja stworzenia „Banku Ziemi”51 w Zasobie

${ }^{48}$ A. Sikorska, Przemiany $w$ strukturze agrarnej indywidualnych gospodarstw rolnych, IERiGŻ-PIB, Warszawa 2013, s. 8.

${ }^{49}$ Dz.U. z 2016 r., poz. 585.

${ }^{50}$ Ustawa z dnia 16 grudnia 2015 r. o zmianie ustawy o kształtowaniu ustroju rolnego, Dz.U. z 2015 r., poz. 2179.

51 J. Mioduszewski, Wptyw nabycia gruntów Skarbu Państwa na funkcjonowanie gospodarstw rolnych z regionu warmińsko-mazurskiego. Raport z badań, Olsztyn 2015, s. 66-67, maszynopis. 
Własności Rolnej Skarbu Państwa. Powierzenie Krajowemu Ośrodkowi Wsparcia Rolnictwa zadania „nabywcy gruntów rolnych niejako z urzędu”, może spowodować wzrost zainteresowania sprzedażą ziemi szczególnie w rejonach, gdzie jej ceny są relatywnie niskie i popyt niewielki. Krajowy Ośrodek Wsparcia Rolnictwa może znaleźć się w sytuacji, gdy będzie niejako zmuszony do nabycia gruntów, a tym samym zaangażowania znacznych środków finansowych. Sytuację mogłoby rozwiązać stworzenie w ramach Zasobu Własności Rolnej Skarbu Państwa „Banku Ziemi”. Właściciele ziemi mogliby wnosić grunty rolne w formie „lokaty” do dzierżawy, sprzedaży bądź bezpłatnego użyczenia za pośrednictwem KOWR. Wdrożenie takiego rozwiązania przyniosłoby wymierne korzyści wszystkim interesariuszom. Korzyścią dla właścicieli gruntów rolnych byłoby uniknięcie długotrwałych procedur formalnoprawnych, bezpieczeństwo zawierania transakcji oraz możliwość uzyskania korzystniejszych warunków sprzedaży, dzierżawy. Agencji takie rozwiązanie mogłoby pomóc usprawnić obrót gruntami rolnymi na rynku bez konieczności angażowania znacznych środków finansowych (publicznych) przeznaczonych na realizację powierzonych zadań wynikających z ustawy o kształtowaniu ustroju rolnego. Stworzenie w Zasobie własności Rolnej Skarbu Państwa „Banku Ziemi” pozwoliłoby też na osiąganie korzyści finansowych wynikających z tytułu uzyskiwania przychodów z prowizji za pośrednictwo i zarządzanie nieruchomościami, czy też marż ze sprzedaży, bez konieczności angażowania środków publicznych.

\section{Podsumowanie}

Dzierżawa gruntów w procesie przekształceń własnościowych w państwowym sektorze rolnictwa trwających od 1992 roku odegrała kluczową rolę. Ogółem przejętych do Zasobu WRSP było 4,744 tys. ha gruntów, z czego większość pochodziła z Państwowych Gospodarstw Rolnych (79\%). Łącznie w analizowanym okresie odbyło się 1409,1 tys. przetargów, z tego większość na sprzedaż ( 1 014,4 tys.), gdzie zaoferowano grunty o powierzchni 3,7 mln ha. Około 32,7\% ogólnej liczby przetargów zostało 
rozstrzygniętych i 1,6 mln ha gruntów trafiło do nabywców. Natomiast w przypadku oferty zagospodarowania gruntów o powierzchni 7,4 $\mathrm{mln}$ ha odbyło się 394,7 tys. przetargów, z których 82,8\% rozstrzygnięto ustalając dzierżawców ponad 4,6 mln ha gruntów. Należy zaznaczyć, że część gruntów Zasobu WRSP była oferowana w przetargach więcej niż jeden raz. Dzierżawa gruntów miała największe znaczenie w początkowym okresie przekształceń własnościowych, gdzie większość gruntów Zasobu była wydzierżawiona, a poziom uzyskiwanych czynszów dzierżawnych kształtował się na poziomie około 2,0 dt pszenicy za 1 ha UR. W wyniku przygotowanych planów restrukturyzacji oraz odbytych przetargów w Zasobie WRSP pozostało według stanu na koniec 2018 roku niespełna 1,4 mln ha, z tego większość znajduje się w dzierżawie (1,02 mln ha). Z przeprowadzonej analizy wynika, że istotny wpływ na zakres, formę, dynamikę zmian i strukturę zagospodarowania gruntów rolnych w procesie przekształceń własnościowych miały wpływ przyjęte rozwiązania formalnoprawne, wynikające m.in. z polityki rolnej państwa, które kształtowały obrót nieruchomościami rolnymi Skarbu Państwa. Charakterystyczne wydaje się być tu dualne postrzeganie gruntów rolnych, które z jednej strony są głównym zasobem wykorzystywanym w produkcji rolniczej, a z drugiej stanowią swoisty kapitał dający dochód (dopłaty bezpośrednie ze środków UE) i systematyczny jego wzrost ze względu na szybko rosnące ceny ziemi. Takie postrzeganie ziemi w warunkach poprawiającej się sytuacji społeczno-gospodarczej zwiększało popyt na ziemię, której użytkowanie umożliwiało osiąganie dodatkowych dochodów (dopłaty bezpośrednie). W tym czasie wysokość uzyskiwanych poziomów czynszów dzierżawnych korespondowała z wielkością uzyskiwanych dopłat do 1 ha użytkowanych gruntów. Odzwierciedleniem takiego podejścia do gruntów rolnych było systematyczne zwiększanie się poziomu czynszów dzierżawnych i cen gruntów rolnych po wejściu Polski do Unii Europejskiej. Dzierżawa rolnicza jako forma zagospodarowania gruntów Zasobu WRSP podniosła ich mobilność, co w konsekwencji przyczyniło się do zwiększenia powierzchni istniejących gospodarstw rolnych oraz tworzenia się nowych gospodarstw wielkoobszarowych. Oprócz tego w sektorze prywatnym następował proces 
koncentracji i zmiany w strukturze obszarowej, gdzie z ogólnej liczby 2137,5 tys. indywidualnych gospodarstw rolnych pozostała ponad połowa. Ogółem ich liczba zmniejszyła się o około 47,8\%, głównie w grupie obszarowej od 2 do 10 ha UR.

W całym analizowanym okresie na próbę wystawiana była trwałość dzierżawy rolniczej, ze względu na okresowe zmiany preferencji form zagospodarowania, dokonywanie częściowych wyłączeń gruntów z dzierżaw wielkoobszarowych, wprowadzanie okresowych korekt poziomu czynszów, a także zmiany podejścia odnośnie do okresów, na jakie mogły być zawierane. Zdobyte doświadczenia dotyczące dzierżawy nieruchomości rolnych przyczyniło się do popularyzacji tej formy w rolnictwie, a przyjęte rozwiązania mogą zostać wykorzystane również w obrocie gruntami prywatnymi w szczególności, że przy szybko rosnących cenach gruntów rolnych, staje się ona atrakcyjną formą umożliwiającą powiększanie obszaru gospodarstw. 